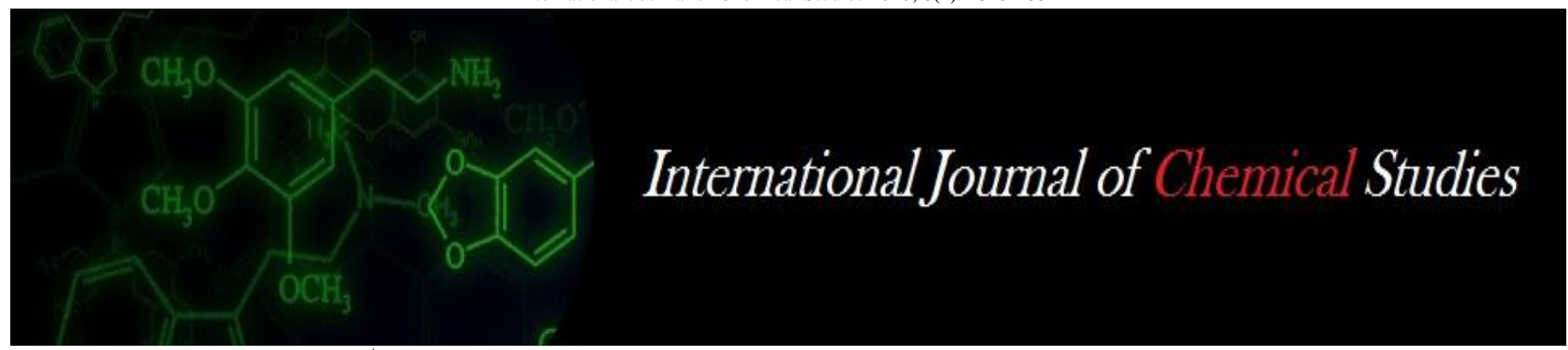

P-ISSN: 2349-8528

E-ISSN: 2321-4902

IJCS 2020; 8(1): 2325-2331

(C) 2020 IJCS

Received: 16-11-2019

Accepted: 19-12-2019

Frishta Samandari

Assistant Professor Department of Biology, Shaheed Prof.

Rabbanni Education University, Kabul, Afghanistan

Mohammad Sharif Arianmal Associate Professor Department of Biology, Faculty of

Education, Paktia University,

Gardiz, Afghanistan

Abdul Wahab Hekmat Associate Professor, Department of Agronomy and Dean Faculty of Agriculture, Paktia

University, Gardiz, Afghanistan

Corresponding Author: Frishta Samandari

Assistant Professor Department of Biology, Shaheed Prof.

Rabbanni Education University, Kabul, Afghanistan

\section{Convergence in Passeriformes species of Kabul province using COX1 mitochondrial gene sequence}

\author{
Frishta Samandari, Mohammad Sharif Arianmal and Abdul Wahab \\ Hekmat
}

DOI: https://doi.org/10.22271/chemi.2020.v8.i1ai.8615

\begin{abstract}
The aim of this survey is study of Passeriformes of Kabul (Afghanistan). Until now it was thought that these birds are monophyletic. However, recent studies determined that many families of Passeriformes are not monophyletic in traditional classification and extensive molecular investigations are the only way to clarify the phylogeny of this group of birds. Sampling was performed from ten stations in the province of Kabul: ten green, Bagram, Surobi, KhakJabbar, Shekardareh, Gol dare, Paghman, Char Asiab, Anderabei and Kafrushy, in three stages between 2015 and 2016, 190 samples were captured using Mist net, and 148 samples were transported to the laboratory. 110 samples of them were belonged to Passeriformes and 38 samples were not. Sparrows that were caught were from 13 families, 23 genera and 35 species of Passeriformes, that family Emberizdae with seven species has the greatest diversity and family Passeridae with 45 individuals has the highest frequency. After morphometric measurements, the samples were transported to the laboratory for molecular studies, DNA was extracted and COX1 gene was sequenced for identification of species and genetic distances. The Bayesian tree indicated the position of species and genera within families and super families. In this study, genus Passer with four species, genus Motacilla with only one species, genus Carduelis with single species, genus Emberiza with six species and genus Serinusa with single species were positioned in superfamily Passerioiodea. Genus Corvus with a single species and genus Lanius with one species were located in clade Corvida. Two species of genus Luscinia, one species of genus Muscicapa and one species of genus Acridotheres were located in superfamily Muscicapoidea. Two species of the genus Hirundo, one species of genus Phylloscopus, one species of genus Ripria, one species of the genus Sitta, one species of genus Sylvia and one species of genus Eremophila were positioned in superfamily Sylvioidea.
\end{abstract}

Keywords: Convergence, Passeriforme, COX1 mitochondrial gene sequence, Kabul, Afghanistan

\section{Introduction}

Accurate identification of wildlife of a country, especially of birds, is a good decision-making criterion for conservation. Therefore, Kabul province, with its good location so far, most of the wild species, especially birds related to sparrows, remain unknown and no complete classification has been made. Kabul Province covers an area of about 3128 square kilometers, equal to one-half percent of the total area of the country (Nuristani, 1972) ${ }^{[28]}$. With dry weather, Kabul province has an average temperature of 40 degrees Celsius above zero and 17 degrees Celsius, with an average rainfall of 100 to $150 \mathrm{~mm}$ per year. The purpose of this study was to obtain the closest distances and closest clusters for evolutionary models, branch lengths and topologies. Bayesian analysis is a statistical method that uses an optimality criterion based on the trait state, except that it does not search for the best tree. In fact, in this method it draws a tree with maximum probability based on information such as evolutionary model, branch length and topology and using the concept of maximum probability. Bayesian analysis, similar to the maximum likelihood analysis of trees, searches for a series of acceptable trees (Roderic and Edward, 1998) ${ }^{[32]}$. Bayesian analysis is applicable to molecular phylogeny, species phylogeny, and species divergence. This method uses a phylogenetic tree and a model based on the expected value of the parameters and their maximum likelihood, to obtain a posterior probability distribution for those parameters. The model is a tree with a specific topology, specific branch length, and a specific spatial pattern of DNA replacement, and has a specific 
distribution rate among nucleotide loci (Philippe et al., 2009). [31]

\section{Materials and Methods}

The three methods, mentioned above, are discrete clustering methods. In general, the method selects the most optimal tree or trees with the least evolutionary variations. The method selects the most likely tree or trees, which is more likely than the whole tree. Bayesian analysis performs the search by applying the maximum concept and targeting the probability distribution of phylogenetic trees (Hall, 2008) ${ }^{[18]}$

\section{Sampled areas}

Sampling was carried out in the Kabul province (the capital of Afghanistan) during two consecutive years (2015, and 2016,) in seven sampling sites as Shawn in fig 1.6 and seven cities in the province of Kabul, including Baghrami, Sorobi, khaki Jabbar, Shakardareh, Guldareh and Paghman. This sampling included the collection of full and muscle for molecular studies, from the sample the species of this order and a number of other types of orders, a total of about 190 samples. Sampling stations are shown on the map of the province of Kabul with a red mark (Fig. 1).

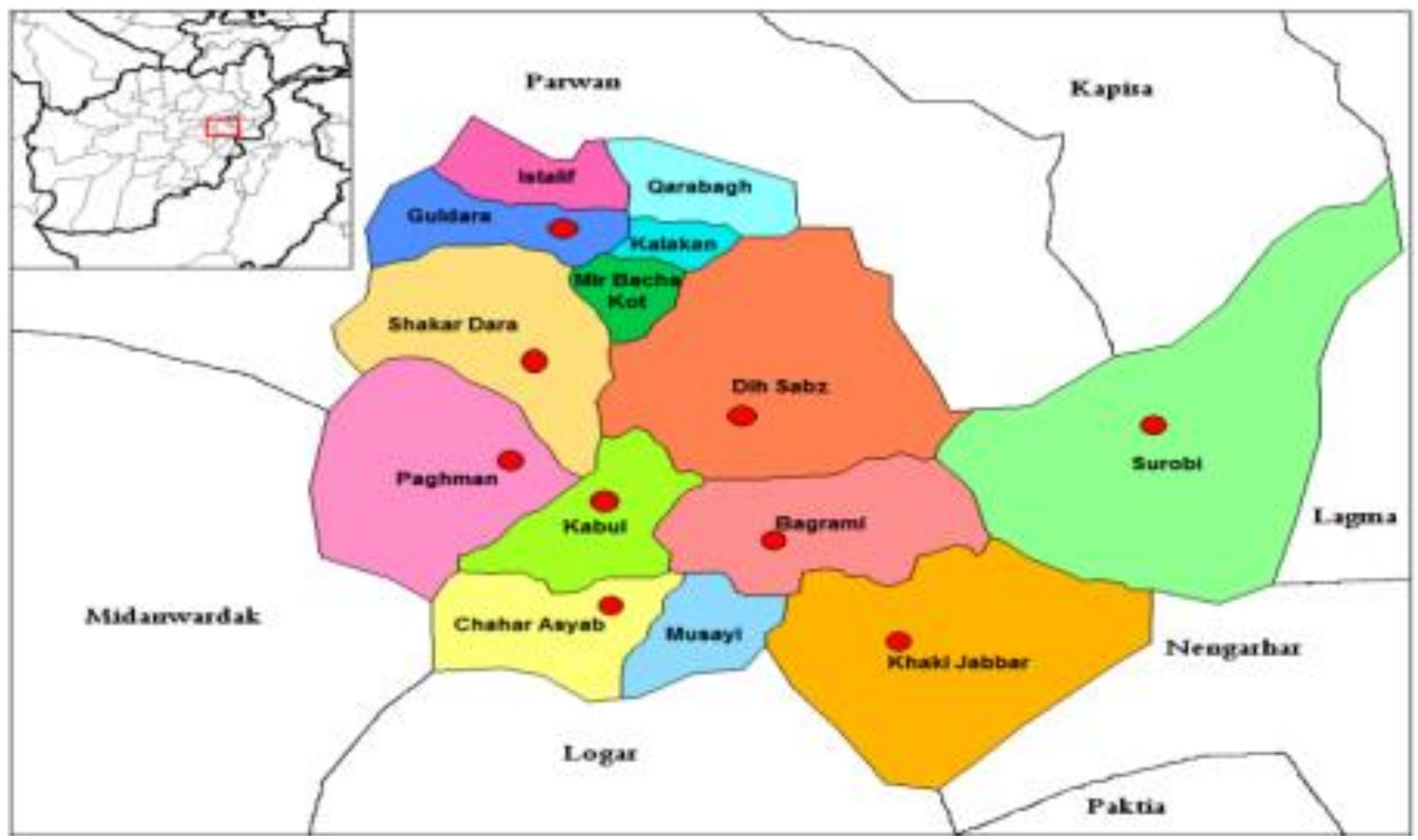

Fig 1: Map of the Kabul Province

The Kabul Central Border, the areas sampled from it them, are marked with red color. During sampling, a number of specimens of different species were found that were not trapped in the sampling net, but their names were given in table (1).

Table 1: Sampling areas with sampling dates and geographical location

\begin{tabular}{|c|c|c|c|c|c|}
\hline Altitude & Latitude & longitude & Sampling date & Sampling number & Sampling area \\
\hline $1917 \mathrm{~m}$ & - & - & 2016 & 4 & Andrabi \\
\hline $1940 \mathrm{~m}$ & - & - & $\begin{array}{l}2016 \\
2016 \\
2016 \\
2015\end{array}$ & $\begin{array}{c}3 \\
2 \\
15 \\
14\end{array}$ & Kafroshi \\
\hline $\begin{array}{l}1748 \mathrm{~m} \\
1748 \mathrm{~m} \\
1748 \mathrm{~m} \\
1748 \mathrm{~m} \\
1749 \mathrm{~m}\end{array}$ & $\begin{array}{l}69^{\circ} 14^{\prime} 54.44^{\prime \prime} \mathrm{E} \\
69^{\circ} 14^{\prime} 54.44^{\prime \prime} \mathrm{E} \\
69^{\circ} 14^{\prime} 54.44^{\prime \prime} \mathrm{E} \\
69^{\circ} 14^{\prime} 40.61^{\prime \prime} \mathrm{E} \\
69^{\circ} 14^{\prime} 40.61^{\prime \prime} \mathrm{E}\end{array}$ & $\begin{array}{l}3438^{\prime} 54.06^{\prime \prime} \mathrm{N} \\
3438^{\prime} 54.06^{\prime \prime} \mathrm{N} \\
3438^{\prime} 54.06^{\prime \prime} \mathrm{N} \\
3483^{\prime} 44.72^{\prime \prime} \mathrm{N} \\
343^{\circ} 83^{\prime} 44.72^{\prime \prime} \mathrm{N}\end{array}$ & $\begin{array}{l}2015 \\
2015 \\
2016 \\
2016\end{array}$ & $\begin{array}{c}5 \\
6 \\
35 \\
22 \\
15\end{array}$ & Dehsabz \\
\hline $\begin{array}{l}1791 \mathrm{~m} \\
1791 \mathrm{~m} \\
\end{array}$ & $\begin{array}{l}69^{\circ} 16^{\prime} 31.61^{\prime \prime} \mathrm{E} \\
69^{\circ} 16^{\prime} 31.61^{\prime \prime} \mathrm{E} \\
\end{array}$ & $\begin{array}{l}3428^{\prime} 63.32^{\prime \prime} \mathrm{N} \\
3428^{\prime} 63.32^{\prime \prime} \mathrm{N}\end{array}$ & $\begin{array}{l}2015 \\
2016 \\
\end{array}$ & $\begin{array}{l}4 \\
1 \\
\end{array}$ & Bagrami \\
\hline $\begin{array}{l}1001 \mathrm{~m} \\
1001 \mathrm{~m} \\
1001 \mathrm{~m}\end{array}$ & $\begin{array}{l}69^{\circ} 44^{\prime} 48.94^{\prime \prime} \mathrm{E} \\
69^{\circ} 44^{\prime} 50.53^{\prime \prime} \mathrm{E} \\
69^{\circ} 44^{\prime} 48.94^{\prime \prime} \mathrm{E}\end{array}$ & $\begin{array}{l}3435^{\prime} 18.09^{\prime \prime} \mathrm{N} \\
3435^{\prime} 19.42^{\prime \prime} \mathrm{N} \\
3435^{\prime} 18.09^{\prime \prime} \mathrm{N}\end{array}$ & $\begin{array}{l}2015 \\
2016 \\
2016\end{array}$ & $\begin{array}{l}5 \\
5 \\
5\end{array}$ & Serobi \\
\hline $2390 \mathrm{~m}$ & $6926,00.09$ "E & $3420100.02 " \mathrm{~N}$ & 2016 & 3 & KhakieJabar \\
\hline $2337 \mathrm{~m}$ & $69 \% 66^{\prime} 51.91 " \mathrm{E}$ & $3424 ' 57.55 " \mathrm{~N}$ & 2016 & 5 & ChaarAsiab \\
\hline $2208 \mathrm{~m}$ & $68^{\circ} 58^{\prime} 41.62^{\prime \prime} \mathrm{E}$ & $3435^{\prime} 05.24^{\prime \prime} \mathrm{N}$ & 2016 & 20 & Paghman \\
\hline $\begin{array}{l}1991 \mathrm{~m} \\
1991 \mathrm{~m}\end{array}$ & $\begin{array}{l}6902 ' 24.70^{\prime \prime} \mathrm{E} \\
6902 ' 24.70^{\prime \prime} \mathrm{E}\end{array}$ & $\begin{array}{l}34^{\circ} 44^{\prime} 41.94^{\prime \prime} \mathrm{N} \\
34^{\circ} 44^{\prime} 41.94^{\prime \prime} \mathrm{N}\end{array}$ & $\begin{array}{l}2016 \\
2016\end{array}$ & $\begin{array}{l}9 \\
4\end{array}$ & Guldareh \\
\hline $1994 m$ & 69 04'18.87"E & $34^{\circ} 41^{\prime} 51.09^{\prime \prime} \mathrm{N}$ & 2015 & 4 & Shakardara \\
\hline
\end{tabular}




\section{Sampling method}

In different habitats, the Misnet was used for catching samples, and by singing the sound of the expected species in each habitat,. After catching the bird (Fig. 2.1.2), it was removed from the net, and photographs were taken from the back, abdomen and lateral surfaces before changing the feathers. Then separate a few samples (such as those from the primary and secondary master bird) and put in a zipper bag. The sample number, the specifications of the sampling site (name of the location, the geographical location) and the sex of the bird were recorded on the envelope. Then, from the chest and muscle of the bird (Fig. 2.1), the tissue samples were taken into vials containing alcohol, and the vials were numbered.

\section{Sampling equipment}

\section{The equipment used in this study were}

Misnet (for catching), GPS for geographical location, binocular, camera, alcohol, containing, containers, vials, enveloper, digital caliper, plaster bags, paper, permanent marker .Invisible net (Misnet) for tracking GPS bird to measure longitude and latitude of area 3 Map of the area, binoculars, cameras, containers containing alcohol to store dead specimens, vials containing alcohol, to fix muscle tissue, envelope, to hold the full Digital caliper for measuring morphological traits, anatomical instruments for removing tissue, plastic box or paper for storing vials, padding for measuring wings, markers

\section{Molecular studies}

For molecular studies, tissues and bird feathers were used.

\section{(a). Separating and storing tissues for molecular studies}

The tissues were kept in alcohol. The tissue size was not too large because the water in the tissue dilutes the alcohols were replaced after a few hours. Different tissues such as muscle, liver and kidney can be used to extract DNA but the molecular tissues were used in this study. The tissue parts were separated from the tissue samples in a completely sterile condition and placed in another vial and the sample number was recorded. The parts are better in size and small in size.

\section{DNA extraction}

Necessary materiel for DNA Extraction

1. Extraction buffer $(\mu \mathrm{L} 140)$

2. Proteinase $\mathrm{k}(\mu \mathrm{L} 10)$

3. Sterile water $(\mu \mathrm{L} 50)$

4. $\mathrm{NaCl}(\mu \mathrm{L} 180)$

5. $10 \% \operatorname{SDS}(\mu \mathrm{L} 80)$

6. Isopropanol $(\mu \mathrm{L} 420)$

7. Ethanol $80 \%(2 \times 250 \mu \mathrm{l})$

\section{DNA extraction steps}

$10 \mu \mathrm{l}$ Proteinase K, $80 \mu \mathrm{l}$ SDS $10 \%$, and $410 \mu \mathrm{l}$ Extraction Buffer were added to the sample containing vial, and were placed in $37 \mathrm{c}$ temperature for 12_244 in a__. After that, the sample were centrifuged at about $13000 \mathrm{rpm}$ for 5 minutes and the supernatant was transferred to a new sterile vial. After adding $180 \mu \mathrm{l}$ of $\mathrm{NaCl}$ to vial, it was again centrifuged for 5 minutes at $13,000 \mathrm{rpm}$. The supernatant was poured into a new sterile vial and added 420 microliters of cold isopropanol to each vial. After mixing the contents of the vial, they were centrifuged for 5 minutes at $13000 \mathrm{rpm}$ and the supernatant was discarded. The contents of the vial were washed with alcohol in two steps and, at each washing step, $250 \mu$ of $80 \%$ ethanol was added to each vial and centrifuged for 5 minutes at about $13000 \mathrm{rpm}$. In the final wash step, in order to completely eliminate the effect of alcohol, they can be placed in a vacuum or in the absence of a vacuum, the vials were left open and placed in the hood for several hours to evaporate the alcohol. After assuring evaporation of alcohol, $50 \mu \mathrm{l}$ of distilled water were added and mixed. After that, the extracted DNA can be stored for a long time at $-20^{\circ} \mathrm{C}$.

\section{Quantifying the quality and quantity of DNA}

The quantity and quality of extracted DNA are measured using a Nanodrope device or electrophoresis gel. In the measurement with a Nano drop device, the device is calibrated with the solution used for diluting the DNA (here were distilled water), and then the amount of 1 microliter of extracted DNA wase placed on the sensitive surface of the device and the genome was studied quantitvely and quantitvely (Fig. 2)

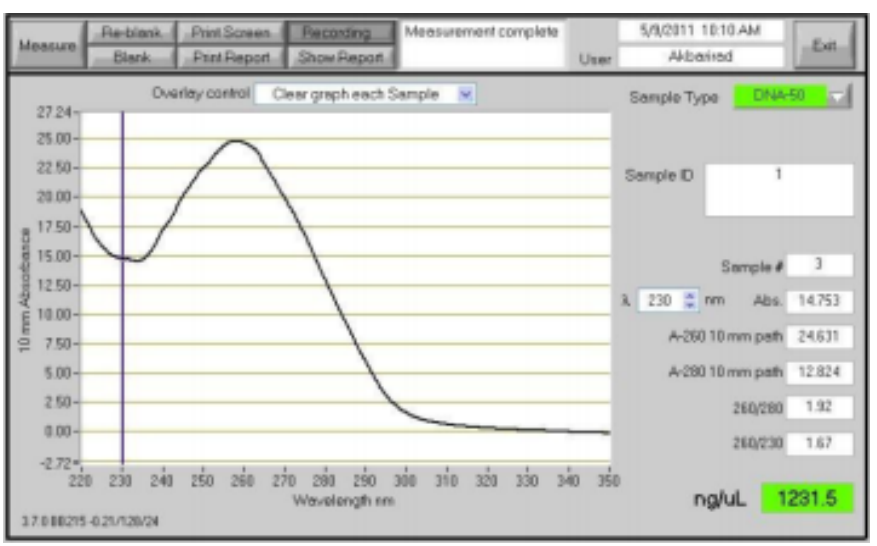

Fig 2: Diagram of DNA Acquiring in Nano drop System.

By using nano drop, the amount of DNA present in the cell is expressed in $n g / \mu 1$, as shown in Figure 2-2, the DNA value in the sample is equal to $2,123 \mathrm{ng} / \mu \mathrm{l}$. The quality of the extracted DNA is calculated based on the wavelength ratio A260/A-280, and it appronatewhene the ratio is between. 1 and 2

\section{Agarose gel electrophoresis}

An electrophoretic gel can also be used to determine the quantity and quality of DNA. The brightness and thickness of the desired bands show good information about the DNA at the extraction stages as well as in the PCR stage. Electrophoresis at the extraction stage can reflect the state of DNA in terms of degeneration and in the PCR stage it can indicate the proliferation of the desired bond or the formation of dimer dimer on the gel.

\section{Preparation of the gel and its buffer}

To make the gel, the following procedure was performed: 0.4 $\mathrm{g}$ of agarose was dissolved in $50 \mathrm{ml}$ of TBX buffer and placed on microwave to clarify the gel solution.

\section{TBX Buffer Material:}

1. TRIS 2. Boric acid 3. EDTA (ethylene diaminetetraacetic acid)

The buffer wase prepared initially $5 \mathrm{X}$ and converted to $0.5 \mathrm{X}$ when used.

To prepare a TBX 5X buffer, $3.44 \mathrm{~g}$ boric acid, $6.75 \mathrm{~g}$ Tris and $2.5 \mathrm{ml}$ EDTA were mixed and by adding distilled water was reached to a volume of $125 \mathrm{ml}$. At the time of use, it was diluted 10 times with distilled water and prepared to $0.5 \mathrm{X}$. 


\section{Preparing the gel to put the samples}

After the mixture of agarose and TBX buffer was cooled slightly, $5 \mu \mathrm{l}$ of Green Viewers was added to it, and was poured into a gel plates whose tow ends were previously sealed with gel. After the gel was formed, the shoulders were removed and the gel was placed in an electrophoresis tank containing $0.5 \mathrm{X} \mathrm{TBX}$ solutions.

\section{Transfer of sink sump well}

After adding $4 \mu \mathrm{l}$ of leading solution to $2 \mu \mathrm{l}$ of PCR product or extraction of DNA, the sample was placed inside the gel well, and the DNA ladder was put in the first well. Then, due to the negativity of the DNA charge, the product was placed in the negative pole to the positive pole on a gel at a voltage of 90 volts. The time required for electrophoresis is 20-15 minutes.

\section{See the gel in the gel documenting machine}

The documenting is used to see bends on the gel and the gel is examined under UV light. With this device you can take a gel image.

\section{Results}

In this chapter, results from the molecular approach were obtained using the gene sequences found in the NCBI and
BOLD gene search engines. In this study, 1240 sequences of the gene bank and 86 sequences from 190 samples of birds captured from Kabul province were investigated in a molecular analysis.

The baysian tree was drawn by MrBayes software for all collected samples from Kabul province. In this study, 82 sequences were assessed from which 81 were from Kabul and one was chosen from gene bank as out of genus sample. The tree was divided mainly into two clades Corvida and Passerida.

\section{Identification of samples of passeriformes in Kabul province}

A total of 190 specimens of passeriformes and non-sparse forests were captured during the study in Kabul province in 2015 and 2016. Based on morphological traits and using valid identification keys from existing samples, 148 samples were selected for morphological and molecular study.

Among 148 samples, 110 specimens were related to other with 13 families, 23 genera and 35 species. Their scientific names based on family presented in table 1 .

Table 2: Birds Species Caught in Kabul Province by Separation of Number, Scientific and local Names and Family

\begin{tabular}{|c|c|c|c|}
\hline S. No & Scientific name & Family name & Number of Sp. \\
\hline 1 & Laniusvittatus & Laniidae & 1 \\
\hline 1 & Laniusschach & Laniidae & 2 \\
\hline 1 & Golden oriol & Oriolidae & 3 \\
\hline 1 & Corvusmonedula & Corvidae & 4 \\
\hline 1 & Alaudaarvensis & Alaudidae & 5 \\
\hline 1 & Eremophilaalpestris & Alaudidae & 6 \\
\hline 1 & Alaudagulgula & Alaudidae & 7 \\
\hline 3 & Calandrellabrachydactyla & Alaudidae & 8 \\
\hline 2 & Hirundorustica & Hirundinidae & 9 \\
\hline 2 & Phylloscopusinornatus & Phylloscopidae & 10 \\
\hline 12 & Sylvia curruca & Sylviidae & 11 \\
\hline 1 & Sittatephronota & Sittidae & 12 \\
\hline 1 & Acridotherestristis & Sturnidae & 13 \\
\hline 1 & Temenuchuspagodarum & Sturnidae & 14 \\
\hline 2 & Lusciniamegarhynchos & Muscicapidae & 15 \\
\hline 2 & Lusciniasvecica & Muscicapidae & 16 \\
\hline 1 & Muscicapastriata & Muscicapidae & 17 \\
\hline 12 & Passer domesticus & Passeridae & 18 \\
\hline 8 & Passer montanus & Passeridae & 19 \\
\hline 3 & Passer hispaniolelsis & Passeridae & 20 \\
\hline 2 & Motacillaflava & Motacillidae & 21 \\
\hline 2 & Anthushodgsoni & Motacillidae & 22 \\
\hline 2 & Anthuspratensis & Motacillidae & 23 \\
\hline 1 & Calandrellabrachydactyla & Alaudidae & 24 \\
\hline 1 & acutirostris & Alaudidae & 25 \\
\hline 2 & Cardueliscarduelis & Fringillidae & 26 \\
\hline 3 & Pyrrhulapyrrhula & Fringillidae & 27 \\
\hline 1 & Serinuspusillus & Fringillidae & 28 \\
\hline 12 & Emberizabruniceps & Emberizidae & 29 \\
\hline 2 & Emberizahortulana & Emberizidae & 30 \\
\hline 8 & Emberizabuchanani & Emberizidae & 31 \\
\hline 1 & Emberizaleucocephalos & Emberizidae & 32 \\
\hline 1 & Emberizacia & Emberizidae & 33 \\
\hline 5 & Emberizamelanocephala & Emberizidae & 34 \\
\hline 9 & Emberizastewarti & Emberizidae & 35 \\
\hline
\end{tabular}

\section{Molecular results of Passeriformes in Kabul province}

A total of 1414 sequences were examined. The 148 collected specimens of birds from the province of Kabul, of which 38 were belonging to different non-asbestos orders, 110 belonged to the passeriformes, and other sequences belonging to the passeriformes in Kabul province were taken from the Gene Bank. 


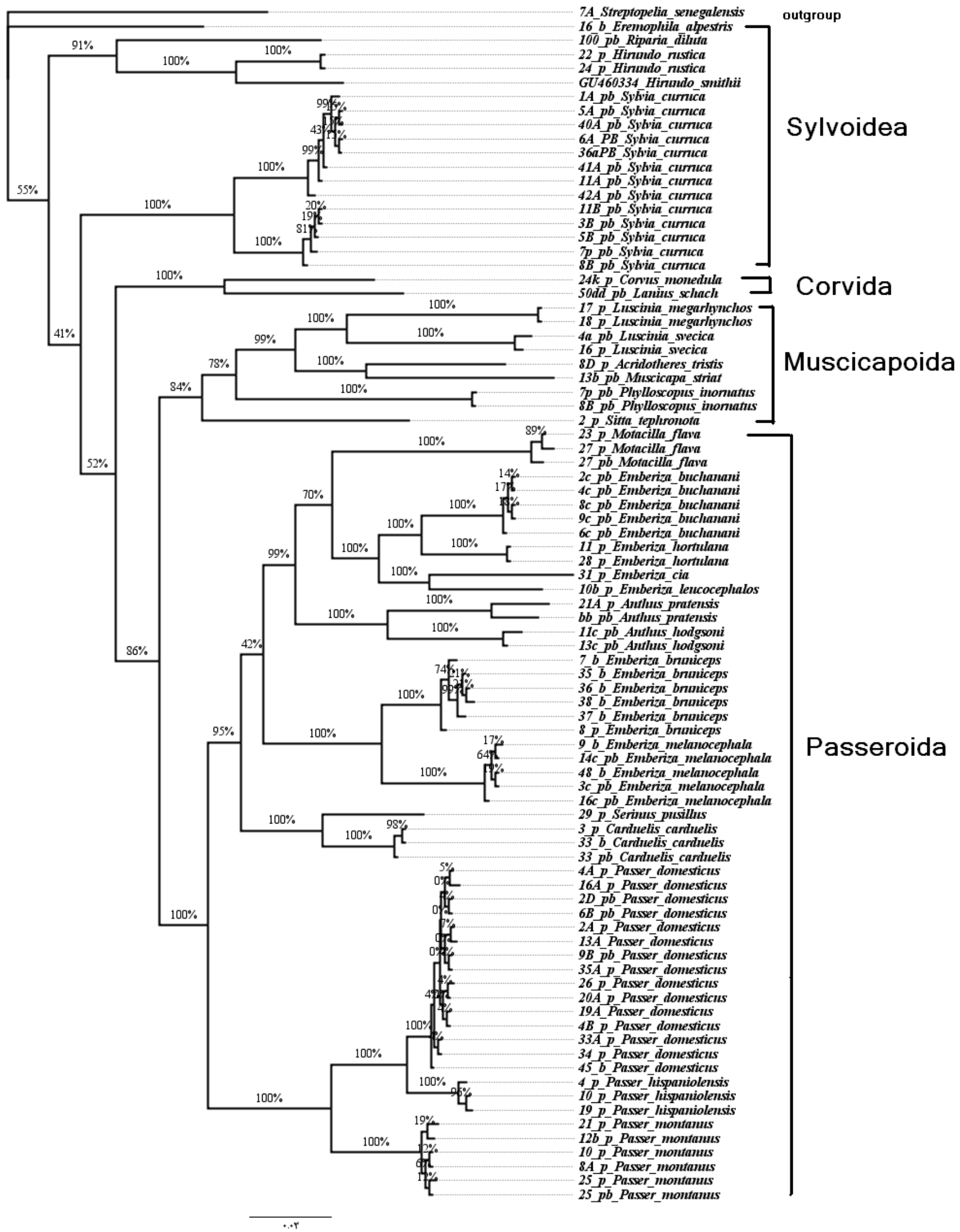

\section{Discussion and Conclusion}

\section{The Taxonomic Situation of the Passeriformes}

Passeriformes includes a mono-descendant species that seems to be a successful group of bird and rapidly separated in the late Tertiary period According to the transitional classification based on the recognition birds are divided into the subclasses (Tyranny) and Oscines (Passer), they were introduced with Acanthisittidae's recent molecular studies as the third chord and the sister group for the two previous clusters. and its molecular traits (Johansson et al., 2001) ${ }^{[22]}$.

On the basic of resent molecule studies a canthi's ttidae was introduced was introduced as Third substance and sisten group Johansson, at al 2001) ${ }^{[22]}$.

The Oscines group, with more than 4500 species, is the largest group with highest global distribution and probably originated from the Australian Region (Johansson, 2008) ${ }^{[22]}$. 
The division of Oscines into tow sisten taxon Sibley and Ahlquist 1990, ${ }^{[34]}$ which was rejected in the recent years, and Corvida was introduced as a paraphilithic group (Barker et al., 2002; Ericson et al. 2002) [10].

Sibley and Ahlquist (1990). [34] defined the cluster for Passerida, including Passerioidea and Sylvioidea, and established Muscicapoidea as a regular group for two other clouds.

In addition to above contradictory phylogenetic hyphothesis has been reported for phylogenetices, sub groups espeacilly with passerida with including muscicapoideasylvioidea and passerida families (Ericoson and johansson, 2003) ${ }^{[16]}$.

Monodescenant (Sibley and Monroe, 1990) ${ }^{[35]}$. For example, the sequences of the RAGI and RAGII markers showed that Paramythiamontium, Toxorhamphus, Oedistoma and Melanocharis, belonging to the Corrvida nucleus in Sibley and Monroe (1990) [35] in the Passeria group (Barker et al., 2004) ${ }^{[11]}$. Also, molecular studies have shown that taxa that are not in the Passerida group may be part of the split. For example, Culicicapa, Chloropsis, Irena, and some other species that were basically in the scavenger group are in the Passerida group (Barker et al., 2004) [11]. The Pseudopodoceshumilis species previously categorized in Corvini (crows) is associated with recent studies in the Passeria family (James et al., 2003) [21]. So far, many molecular studies have been carried out on passeriformes, but the largest number of taxon studied from passeriformes has been studied in research is 173 taxa of passeriformes (Beresford et al., 2005) ${ }^{[11]}$. Typically, most studies have been based on one or more nuclear genes as phylogenetic markers, and the use of several molecular markers has been proven, but so far few studies have used the combination of more than two molecular markers (Moore, 1999) ${ }^{[27] .}$

\section{Bayesian tree analysis of the COX1 mitochondrial gene}

The bayesian tree was mapped using the amplified COX1 gene sequences from the Kabul province and the gene bank. The positioning of genera and species within families and superfamilies' is similar to the results of DNA hybridization studies, conducted by Sibley and Ahlquist (1990) ${ }^{[34]}$ for sparrows. Sparrows are a very large single-species group whose relationships are well known at least at higher taxonomic levels by DNA sequencing. However, new studies show that many families of sparrows in the traditional classification are not monophyletic. Understanding of the phylogeny of sparrows is possible when more extensive gene sequences are available. Based on DNA hybridization (Sibley and Ahlquist, 1990) ${ }^{[34]}$ and nuclear gene sequences (Barker et al., 2002) ${ }^{[10]}$, three major clades of sparrows have been shown to conventionally include Sylvioidea, Muscicapoidea and Passeroidea, The final bayesian tree of this research is also shown.

Passer genus with four species, Motacilla genus with one species, Carduelis genus with one species, Emberiza genus with six species and Serinusa genus with one species included in the family Passerioiodea. Corvusgenus with one species and Laniusgenus with one species are also found in the Corvida clade. Two species of Luscinia with one species of Muscicapa and one species of Acridotheres belong to the family Muscicapoidea. Two species of Hirundo, one species of Phylloscopus, one species of Ripria, one species of Sitta, and one species of Sylvia and one species of Eremophila are located in super-family Sylvioidea.

\section{References}

1. Aliabadian M, Bagherian A, Barzgari AA. Birds. Sokhan Gostar Publishing House (In Persian Language), Iran, 2009.

2. Arianmal M, Sharif. Classification and Molecular Identification of Passeriform Birds in Kabul Afghanestan. Ferdowsi University of Mashhad. Faculty of Science. Department of Biology. M.sc Thesis, 2014.

3. Mutawazi GH. Environment in Afghanistan. Islamic Association of Afghan Engineers. Peshawar, 1998.

4. Mansouri C. Guidance for Iranian Birds.Farzaneh Publishing, Tehran, Iran, 2008.

5. Nasiri M. The textbook of the first workshop on DNA molecular markers in livestock rearing.Faculty of Agriculture, Ferdowsi University of Mashhad, Iran. Natural Resources and Animal Libraries Research Center of Khorasan, 2001.

6. Aliabadian M, Kaboli M, Nijman V, Vences M. Molecular Identification of Birds: Performance of Distance-Based DNA Barcoding in Three Genes to Delimit Parapatric Species, 2009.

7. Ali S, Ripley SD. Handbook of the birds of India and Pakistan. Oxford: Oxford University Press, 1973.

8. Alonso JC. Kreuzung spanischer Haus - (Passer domesticus) und Weidensperlinge (Passer hispaniolensis) in Gefangenschaft. Journal fürOrnithologie. 1984; 125:339-340.

9. Avibase (ioc v2.11), the world bird database - Lepage, D. 2012.

10. Barker FK, Barrowclough GF, Groth JG. A phylogenetic hypothesis for passerine birds: taxonomicand biogeographic implications of an analysis of nuclear DNA sequence data. Proceeding of Royal Society. 2002; 269:295-308.

11. Beresford P, Barker FK, Ryan PG, Crowe TM. African endemics span the tree of songbirds (Passeri): Molecular systematics of several evolutionary "enigmas". Proceeding of Royal Society. 2005; 272:849-858.

12. Britannica Illustrated Science Library Staff. Birds Encyclopedia Britannica, Inc., 2008.

13. Bureš S, Nadvornik P, Saetre GP. Hybridization and apparent hybridization between Meadow Pipit (Anthuspratensis), 2002.

14. Clement P. Kennzeichen und Taxonomievon Bechsteindrossel Turdusruficollis und. Naumanndrossel, T. naumanni. Limicola. 1999; 13:217-250.

15. Ericson PGP, Christidis, L, Cooper A, Irestedt $M$, Jackson J, Johansson US and Norman JA. A Gondwanan origin of passerine birds supported by DNA sequences of the endemic New Zealand wrens. Proceeding of Royal Society. 2002; 269:235-241.

16. Ericson PGP, Johansson US. Phylogeny of Passerida (Aves: Passeriformes) based on nuclear and mitochondrial sequence data, Molecular Phylogenetic Evolution. 2003; 29:126-138.

17. Habibi K. The Mammals of Afghanistan. Zoo outreach organization Koimbator, Hindostan, 2004.

18. Hall BG. Phylogenetic trees made easy, a how-to manual, 3nd edition. Sinauer Associates, Inc., 2008.

19. Hebert PDN, Stoeckle MY, Zemlak TSC, Francis M. Identification of Birds through DNA Barcodes. Plos Biology. 2004; 2:1657-1663.

20. Hopkinson. Records of birds bred in captivity.London: H. F. \& G. Witherby, 1926. 
21. James HF, Ericson PGP, Slikas B, Lei FM, Gill FB, Olson S. Pseudopodoceshumilis, a misclassified terrestrial tit (Paridae) of the Tibetan Plateau: Evolutionary consequences of shifting adaptive zones. Ibis. 2003; 145:185-202.

22. Johansson US, Parsons TJ, Irestedt M, Ericson PGP. Clades within the higher land birds', evaluated by nuclear DNA sequences. Zoolgy Sysemitics. Evolution Research. 2001; 39:37-51.

23. Johansson US, Fjeldså J, Bowie CK. Phylogenetic relationships within Passerida (Aves: Passeriformes): A review and a new molecular phylogeny based on three nuclear intron markers. Molecular Phylogenetic Evolution. 2008b; 48:858-876.

24. Jiguet F, Defos du Rau P. Hybrideproba-ble Mouetterieuse Larusridibundus $\times$ Goélandcendré Laruscanus. Ornithos. 2003; 10:44-45.

25. Johnson RR, Haight LT, Ligon JD. Strickland's Woodpecker (Picoidesstricklandi),no. 474, Birds of North America, (eds.) A. Poole, F. Gill. Philadelphia: Birds of North America, 1999.

26. Mayaud. The races of Motacilla flava breed-ing in France. The Ibis. 1949; 91:171-172.

27. Moore SS, Whan V, Davis GP, Byrne K, Hetzel DJS, Preston N. The development and application of genetic markers for the Kuruma prawn Penaeusjaponicus. Aquaculture. 1999; 173:19-32.

28. Nuristani, 1972. Afghanistan Environment, Department of Biology. Kabul University Press Kabul Afghanistan.

29. Panov EN, Grabovsky VI, Ljubustchenko SV. Divergence and hybridpolymorphism in the complex "Eastern Pied Wheatears", Oenanthepicata. Zoologicheskii Zhurnal. 1993; 72:80-96.

30. Parkin DT, Collinson M, Helbig AJ, Knox AG, Sangster G. The taxonomic status of Carrion and Hooded crows. British Birds. 2003; 96:274-290.

31. Philippe L, Macro S, Anne-Mieke V. The Phylogenetic Handbook: A Practical Approach to Phylogenetic Analysis and Hypothesis Testing. Ambridge University Press, 2009.

32. Roderic DMP, Edward CH. Molecular Evolution: A Phylogenetic Approach. Blackwell Publishing, 1998.

33. Shirihai H, Gargallo G, Helbig AJ. Sylvia Warblers. Princeton: Princeton University Press, 2001.

34. Sibley CG, Ahlquist JE. Phylogeny and Classification of Birds. Yale University Press, New Haven, CT, 1990.

35. Sibley CG, BL Monroe. Distribution and Taxonomy of the Birds of the World. Yale University Press, New Haven, CT, 1990.

36. Tavares ES, Baker AJ. Single mitochondrial gene barcodes reliably identify sister-species in diverse clades of birds). Evolutionary Biology. 2008; 8:81.

37. Takagi M. [Plumage, morphology, distribution and breeding ecology of theBull-headed Shrike on MinamidaitoIsland]. Journal of the Yamashina Institutefor Ornithology. 2000; 32:13-23.

38. Urquhart E. Stonechats: A guide to the genus Saxicola. New Haven: Yale University Press, 2002. 